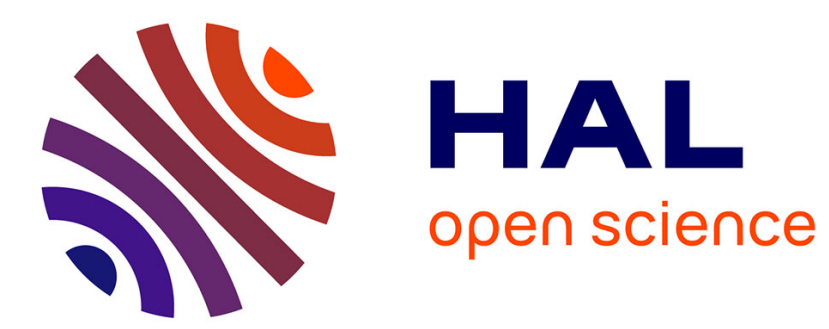

\title{
DETERMINATION OF ELECTRON BEAM CHARGING CONDITIONS OF OXIDES AT LOW ENERGY IN THE LOW DOSE RANGE
}

M. Valenza, Pascal Girard, B. Pistoulet

\section{- To cite this version:}

M. Valenza, Pascal Girard, B. Pistoulet. DETERMINATION OF ELECTRON BEAM CHARGING CONDITIONS OF OXIDES AT LOW ENERGY IN THE LOW DOSE RANGE. Journal de Physique

Colloques, 1989, 50 (C6), pp.C6-174-C6-174. 10.1051/jphyscol:1989628 . jpa-00229659

\section{HAL Id: jpa-00229659 \\ https://hal.science/jpa-00229659}

Submitted on 1 Jan 1989

HAL is a multi-disciplinary open access archive for the deposit and dissemination of scientific research documents, whether they are published or not. The documents may come from teaching and research institutions in France or abroad, or from public or private research centers.
L'archive ouverte pluridisciplinaire HAL, est destinée au dépôt et à la diffusion de documents scientifiques de niveau recherche, publiés ou non, émanant des établissements d'enseignement et de recherche français ou étrangers, des laboratoires publics ou privés. 
REVUE DE PHYSIQUE APPLIQUEE

Colloque C6, Supplément au $n^{\circ} 6$, Tome 24 , Juin 1989

\title{
DETERMINATION OF ELECPRON BEAM CHARGING CONDITIONS OF OXIDES AT LOW ENERGY IN THE LOW DOSE RANGE
}

\author{
M. VALENZA, P. GIRARD and B. PISTOULET \\ Laboratoire d'Automatique et de Microélectronique de Montpellier, CNRS \\ UA-371, Université des Sciences et Techniques du Languedoc, Place \\ Eugène Batailion, F-34060 Montpeliter Cedex, France
}

\begin{abstract}
Scanning Electron Microscope (SEM) voltage contrast techniques proved to constitute a valuable tool for testing integrated circuits (IC). However, the active components may be damaged by electron beam irradiation, so that it is of great importance to determine accurately the allowable limits.
\end{abstract}

Differents types of effects arise and starting from high to low primary energies, two zones may be distinguished. In the case of classical Mos transistors, if the primary electron ( $P E$ ) penetrate down the gate oxide, strong charging effects result (1) but if the PE are located on the top oxide above the polysilicon gate only existing flaws inside the gate oxide are influenced by reemitted photons. So the sensitivity of the observed threshold voltages shifts are strongly dependent on the incident beam energy (1,2): In the case of the floating gate MOS transistors, due to the fact the deposited charges by the electrons on the top oxide are not electrostaticaly screened, an additional channel conductance modulation occurs.

The purpose of this paper is to show the achievement of e-beam charging evaluations. on insulators using MOS floating gate transistors. This method is achievable in classical SEM without any additional surface preparation.

We present the different ways to obtain quantitative results using either a couple of classical and floating gate transistors either a controlled gate element. The equations governing the electrical characteristics of the floating gate MOS transistors are derived, they show good agreement with the experimental results. The deposited charges may be evaluated both in 1 inear or saturation regions of the devices essuming a previous characterization of the technology used. The negative charging evaluation are obtained in the $2-6$ $\mathrm{keV}$ range and our method allows the determination the following magnitudes $1.10^{-9}-1.10^{-6} \mathrm{C} . \mathrm{cm}^{-2}$. Basing on these results, it is shown that surface charge exchanges are necessary to fit experiments and theory in the range considered.

Finally, we have shown the possibility of e-beam charging evaluations on microelectronics insulators, using simple MOS devices, with good accuracy and sensitivity.

\section{REFERENCES :}

1- K. Nakamae, H. Fujioka, K. Ura, Measurements of deep penetration of low energy electrons into metal-oxide-semiconductor structure. J. Appl. Phys. $52(3)(1981)$ p. 1306.

2- P.Girard, Developments in voltage contrast, Scanning Microscopy, 2, 1 (1988) 151 . 